\title{
Effect of Long-Term Simulated Microgravity on Some Sexual Traits of Male Japanese Quail
}

\author{
P. ŠKROBÁNEK ${ }^{1}$, M. BARANOVSKÁ ${ }^{1}$, B. Š́́RNIKOVÁ ${ }^{1}$, M. ZEMAN ${ }^{1,2}$, \\ M. OKULIAROVÁ ${ }^{2}$
}

${ }^{1}$ Institute of Animal Biochemistry and Genetics, Slovak Academy of Sciences, Ivanka pri Dunaji, Slovak Republic, ${ }^{2}$ Department of Animal Physiology and Ethology, Faculty of Natural Sciences, Comenius University, Bratislava, Slovak Republic

Received October 4, 2011

Accepted March 16, 2012

On-line June 6, 2012

\section{Summary}

The aim of this study was to investigate the effects of long-term stay of Japanese quail in simulated microgravity on some sexual features of males. As a model for simulating microgravity exposure of birds in laboratory conditions was used hypodynamia. The mean left testis weight in males reared under hypodynamia from day 3 up to 180 days of age was lower than that of control $(P<0.05)$, but the right testis weight differences between both groups were not significant. Also the area, volume and foam production of cloacal gland was not significantly decreased in hypodynamia birds at the end of experiment. By contrast, the plasma testosterone concentration of males living in hypodynamia was reduced about $50 \%$ at 90 and 180 days of age in comparison to control $(P<0.05)$ suggesting some negative effects on sexual development. Our results demonstrated that male quail kept under simulated microgravity conditions were sexually competent although their sexual efficiency was reduced especially in terms of plasma testosterone.

\section{Key words}

Hypodynamia - Body weight - Cloacal gland - Testes • Testosterone

\section{Corresponding author}

P. Škrobánek, Institute of Animal Biochemistry and Genetics, Slovak Academy of Sciences, Moyzesova 61, 90028 Ivanka pri Dunaji, Slovak Republic. Fax: + 4210245943932 . E-mail: peter.skrobanek@savba.sk

\section{Introduction}

The first time in history, in 1979 , it was found that Japanese quail embryogenesis can successfully realize under conditions of weightlessness (Sabo et al. 1984). Later, in 1990, it was found that microgravity does not have a negative impact on hatching of Japanese quail (Bod'a et al. 1992). At the time, six vital Japanese quail were hatched onboard the Mir space station. Another successful hatching of Japanese quail in weightlessness was carried in 1999 (Sabo et al. 2001). Nevertheless, it is not known how microgravity can influence postembryonic development of Japanese quail chicks during different ontogenetic phases.

A partial answer may be provided by experimental models of simulated microgravity. Based on the comparison of space-flight and ground experiments, it was confirmed that weightless simulations induce similar, although not always identical physiological responses. For example in rats, it was found that spaceflight and earth-based unloading produce similar effect on skeletal muscle (Tischler et al. 1993) and cardiac mass (Ray et al. 2001). Moreover, the motor function of animals exposed to real microgravity was consistent after landing with that seen in rats under simulated microgravity (Walton 1998).

Models for simulating several aspects of weightlessness exist for various species. A $6^{\circ}$ head-down bed rest is used in humans (Gretebeck and Greenleaf 1999). Immobilization by chair restraint is applied in nonhuman primates (Florence et al. 1995). Hindlimb unloading in a $30^{\circ}$ head-down position is used on rodents 
(Morey-Holton and Wronski 1981). Model for simulation of weightlessness in birds is hypodynamia, where an individual is placed in special jacket suspended in a separate cage so that its legs cannot touch the floor (Sabo et al. 1998).

Hypodynamia has been first successfully used in the study of neurophysiological response of adult Japanese quail to a restraint from 5 to 90 days (Juráni et al. 1984). Later, many experiments examining the effect of hypodynamia on various physiological functions in quail were conducted (Gažo et al. 1990, Guryeva et al. 1998). The first four juvenile birds were reared under hypodynamia in 2000 (Škrobánek et al. 2001). Further studies investigated the effects of hypodynamia on postnatal growth and development of Japanese quail from hatch to 63 days of age (Škrobánek et al. 2004, 2008).

The present study was designed to evaluate the effect of long-term stay Japanese quail in simulated microgravity on some sexual features of males.

\section{Materials and Methods}

Eighty 3-day old male Japanese quail (Laying Line 01 Ivanka pri Dunaji) with mean body weight $10.43 \pm 0.75 \mathrm{~g}$ were assigned at random into experimental group ( $\mathrm{n}=40$, exposed to hypodynamia) and control $(n=40)$. Hypodynamia is a method of weightlessness simulation where birds are placed in special individual slings suspended by a flexible metal device such that their legs cannot touch the floor (Škrobánek et al. 2004). Control quail chicks were placed in two rearing boxes $(0.6 \times 0.6 \times 0.3 \mathrm{~m})$. Birds of both groups were kept 180 days in a windowless poultry room with controlled ventilation and heating by infrared lamps. The temperature in the rearing room was maintained at $35-36{ }^{\circ} \mathrm{C}$ for the first few days after hatching and then decreased gradually during four weeks to about $22{ }^{\circ} \mathrm{C}$, remaining on this level until the end of experiment. A commercial starter mass HYD-13 and water were available ad libitum. The diet containing $260 \mathrm{~g} / \mathrm{kg}$ protein and 11.5 MJ metabolisable energy/kg was fed from hatch to the termination of experiment. Lighting in the rearing room was continuous. The care and use of animals were in accordance with laws and regulations of the Slovak Republic and were approved by the Ethics Committee of the Institute of Animal Biochemistry and Genetics, SASci, Ivanka pri Dunaji.

At 90 and 180 days of age, twenty birds from each group were randomly selected and individual body weight was recorded. Subsequently, the cloacal gland size (length and width) was measured by calliper. The cloacal gland volume was calculated according to the formula: $4 / 3 \times 3.5414 \times(0.5 \times$ width $) \times(0.5 \times \text { length })^{2}$ proposed by Chaturvedi et al. (1993). The cloacal gland foam production was determined by subjective scaling of the amount of foam ejected upon manual expression (squeezing) of foam gland, using a scale of 1 (no foam expressed) to 5 (maximum amount of foam expressed). Then, the birds were euthanized by decapitation and blood for testosterone analysis was collected into heparinized plastic tubes. The blood samples were immediately placed on ice, centrifuged at 1,500 $\mathrm{g}$ for $30 \mathrm{~min}$ at $4{ }^{\circ} \mathrm{C}$ to separate the plasma and stored at $-20^{\circ} \mathrm{C}$ until analyzed. Testosterone was determined by direct radioimmunoassay (RIA) partially modified by Zeman et al. (1986). Immediately after blood collection, the abdominal cavity was opened and the testes were removed and measured (length, width and weight).

Data from both groups were analyzed by twoway analysis of variance (ANOVA) with age and treatment as factors. In each analysis, significant differences among means were detected using Tukey multiple comparison test. In all cases, the level of significance was set at $P<0.05$. All values are presented as mean \pm standard deviation.

\section{Results}

The mean body weight of males Japanese quail reared under hypodynamia was lower than that of agematched control housed on the floor in boxes at 90 and 180 days of age $(P<0.05)$. No interaction was observed between age and rearing method (Fig. 1).

The cloacal gland area of control and hypodynamia males increased with age $(P<0.05)$, but the differences between groups were not significant (Fig. 2). Similarly, the cloacal gland volume enlarged at 180 days compared to 90 days of age $(P<0.05)$, however, there was no significant difference between both groups. The foam production of test and control group decreased significantly at 180 days of age $(P<0.05)$. The differences between groups occurred only at 90 days of age $(P<0.05)$.

The mean testicular weight in both male groups varied only slightly during experiment (Fig. 3), although the testes of control group were heavier $(P<0.05)$. Also, the testicular length in both groups was nearly unchanged and the differences between groups were not significant 


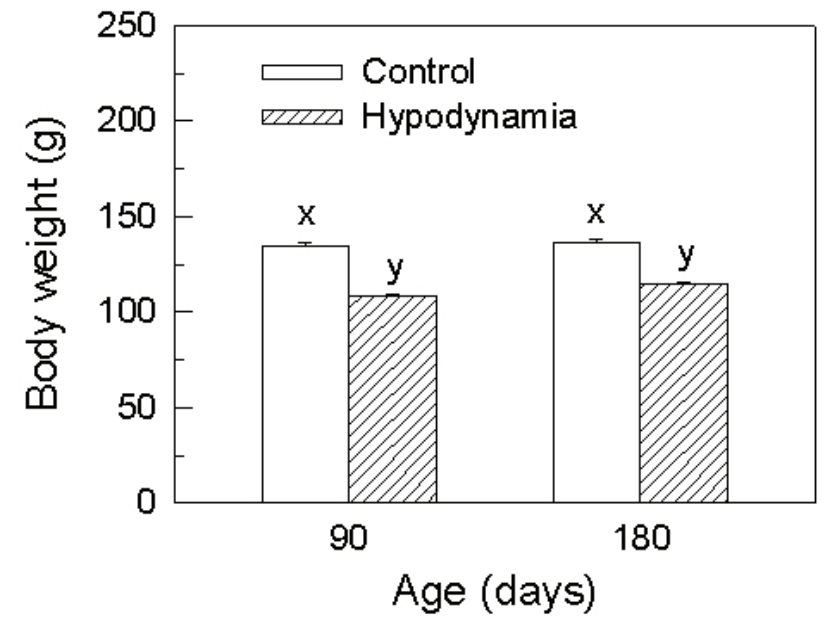

Fig. 1. The body weight of male Japanese quail developing in the simulated microgravity. Values are means \pm S.E.M., $n=18$. $(\mathbf{x}, \mathbf{y})$ Means of control and hypodynamia with different superscripts are significantly different $(P<0.05)$.

except in right testis at 90 days of age. Similarly, the mean testicular width in both male groups was nearly invariable, although the testes of hypodynamia group were shorter $(P<0.05)$.

The mean concentration of testosterone in blood plasma decreased slightly at 180 days compared to 90 days of age (Fig. 4), but the level of testosterone in males under hypodynamia was about half lower than that in control birds $(P<0.05)$.

\section{Discussion}

The purpose of this study that represents a continuation of our previous research was to investigate whether the nearly half-year stay (177 days; from 3 to 180 days of age) in simulated microgravity affects the development of some sexual traits of Japanese quail males. On the basis of our previous results, we hypothesized that hypodynamia can modify the level of studied parameters. The present findings revealed that hypodynamia significantly effected body weight, testis parameters and plasma testosterone concentration. Results are in line with our previous study when Japanese quail males were exposed to simulated microgravity only during 67 days (from 3 to 70 days of age) (Škrobánek et al. 2009). The most likely explanation for these differences might be stress in the first days of bird's life that caused a decrease of food intake and conversion, and removing of weight bearing loads from feet and a permanent absence of free movement that is an essential factor for the normal development of animal organism.

The direct comparison of current results with
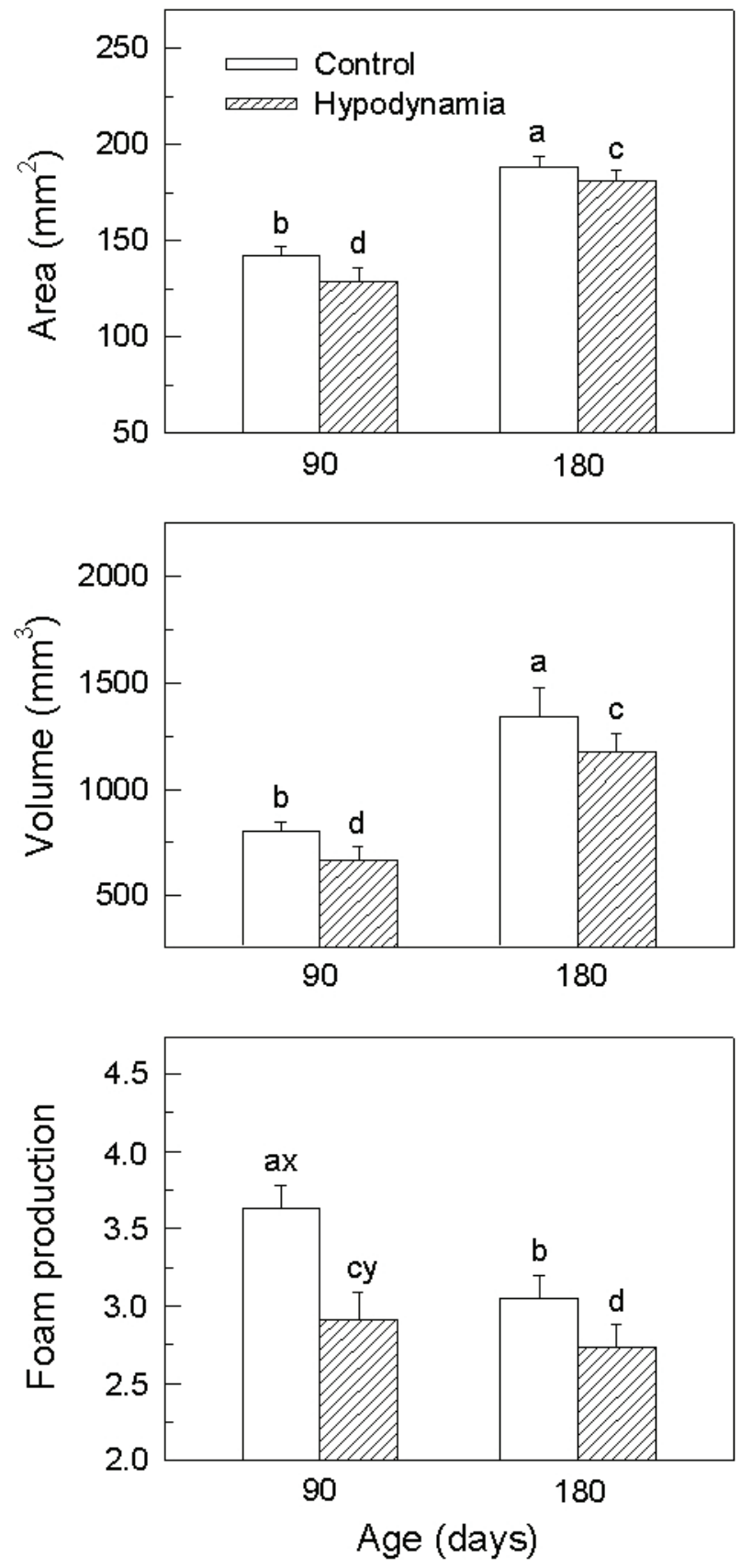

Fig. 2. The cloacal gland area, resp. volume, and foam production of male Japanese quail developing in the simulated microgravity. Values are means \pm S.E.M., $n=18$. $(\mathbf{a}, \mathbf{b})$ Means of control with different superscripts are significantly different $(P<0.05)$, (c, d) Means of hypodynamia with different superscripts are significantly different $(P<0.05),(\mathbf{x}, \mathbf{y})$ Means of control and hypodynamia with different superscripts are significantly different $(P<0.05)$.

data of other studies is impossible because to our knowledge this is the first report investigating effects of long-term simulated microgravity on the postembryonic sexual development of male birds. However, more information is available from the similar studies on mammals. Their results suggest that mammalian reproduction may be reduced under conditions of altered 

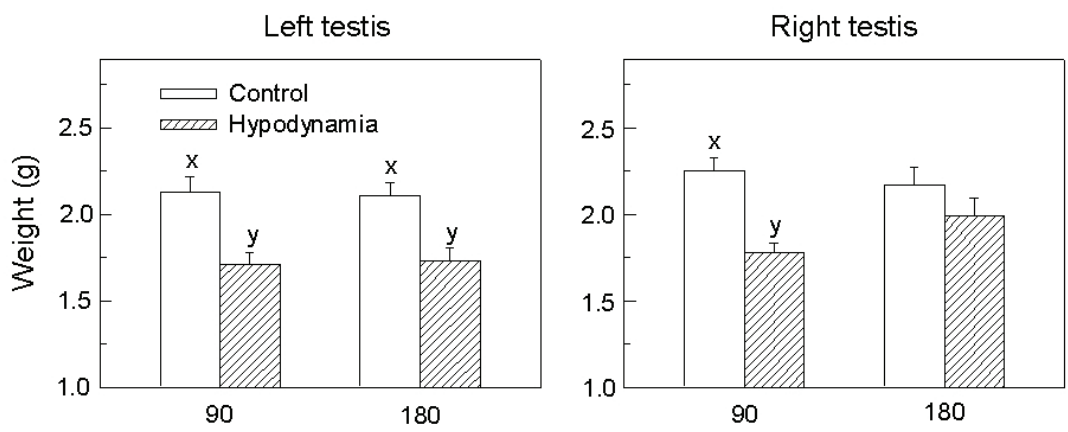

Fig. 3. The testes weight and testes measurements of male Japanese quail developing in the simulated microgravity. Values are means \pm S.E.M., $n=18 .(\mathbf{x}, \mathbf{y})$ Means of control and hypodynamia with different superscripts are significantly different $(P<0.05)$.
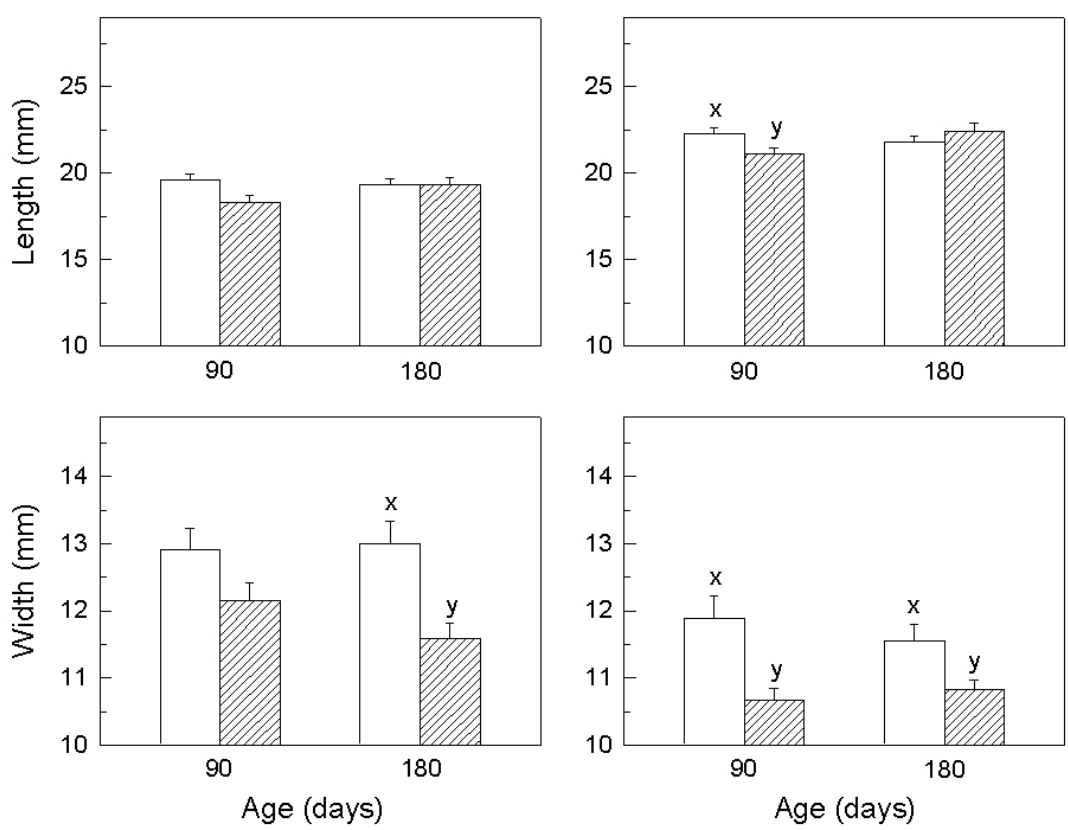

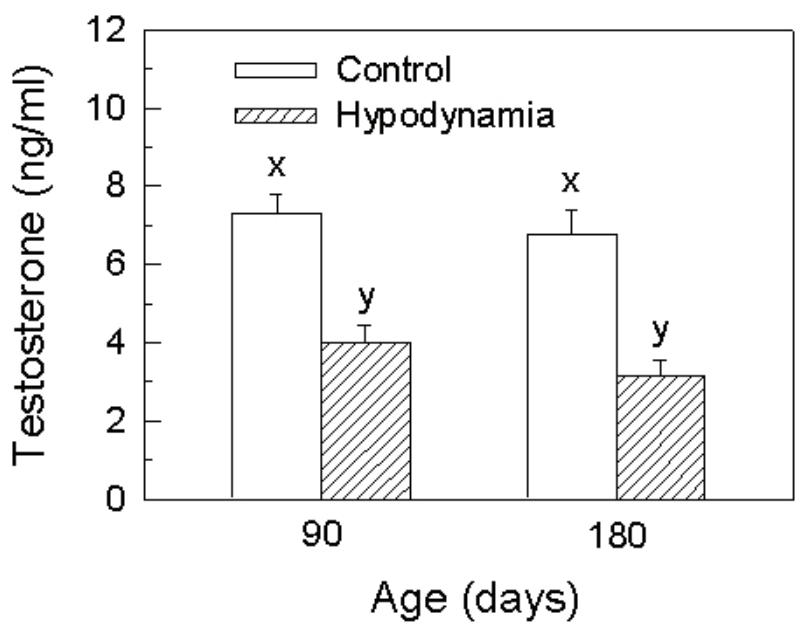

Fig. 4. Concentration of plasma testosterone in male Japanese quail developing in the simulated microgravity. Values are means \pm S.E.M., $n=18$. $(\mathbf{x}, \mathbf{y})$ Means of control and hypodynamia with different superscripts are significantly different $(P<0.05)$.

gravity. For example, in the short-term experiments ( $<14$ days) investigating the reproduction of mice during their exposure to simulated microgravity, a significant decline in testicular weight and testosterone concentration was observed in comparison with free roaming animals (Kamiya et al. 2003, Sharma et al. 2008). Rats exposed to simulated microgravity (6 wk) using the hind-limb suspension exhibited significantly decreased testicular weight, testosterone level and spermatogenesis (Tash et al. 2002). The similar differences in reproductive parameters of rat compared to the ground control were observed in a real microgravity during spaceflight (Sapp et al. 1990, Amman et al. 1992). In humans, a rapid decline in plasma testosterone concentration was consistently recorded in astronauts during Space Shuttle flights (Strollo et al. 1998).

The results of the present experiment clearly demonstrated that sexual development proceeded under conditions of long-term hypodynamia, although these conditions had negative effects on some investigated sexual traits of male Japanese quail. Obtained results are in accord with those found in rodents. These findings confirm that quail is capable of long term living under the conditions of hypodynamia. Together with our previous experiments, this data may be useful for understanding Japanese quail ontogeny during exposure to real 
microgravity.

\section{Conflict of Interest}

There is no conflict of interest.

\section{Acknowledgements}

This work was supported by the Grant Agency for Science of the Slovak Republic, VEGA grant No. 2/0047/09.

\section{References}

AMANN RP, DEAVER DR, ZIRKIN BR, GRILLS GS, SAPP WJ, VEERAMACHANENI DN, CLEMENS JW, BANERJEE SD, FOLMER J, GRUPPI CM: Effects of microgravity or simulated launch on testicular function in rats. $J$ Appl Physiol 73 (2 Suppl): 174S-185S, 1992.

BOĎA K, SABO V, JURÁNI M, GURYEVA TS, KOČIŠOVÁ J, KOŠŤÁL L, LAUKOVÁ A, DADASHEVA OA: Embryonic development and behaviour of Japanese quail exposed to microgravity. Acta Vet Brno 61: 99-107, 1992.

CHATURVEDI CM, BHATT R, PHILLIPS D: Photoperiodism in Japanese quail (Coturnix coturnix japonica) with special reference to relative refractoriness. Indian J Exp Biol 31: 417-421, 1993.

FLORENCE G, RIONDET L, MALECKI H, BLANQUIE JP, MARTIN F, VISO M, MILHAUD CL: A restraining system for rhesus monkeys used in space research. J Med Primatol 24: 61-67, 1995.

GAŽO M, BOĎA K, JANKELA J, BOZNER A, KOČIŠOVÁ J, VÝBOH P, BARANOVSKÁ M, SABO V, DOSTÁL J, STRÁŽNICKÁ H: The effect of hypergravitation, hypodynamy and their combination on the organism of Japanese quail. In: Current Trends in Cosmic Biology and Medicine. K BOĎA (ed), I. Volume. Proceeding of the XXIII International Symposium on Cosmic Biology and Medicine within the Intercosmos Programme, Košice, CSFR, 1990, pp 293-300.

GRETEBECK R, GREENLEAF J: Utility of ground-based simulations of weightlessness. In: Nutrition in Spaceflight and Weightlessness Models. HW LANE, DA SCHOELLER, FL BOCA RATON (ed), CRC Press, New York, 1999, pp 69-96.

GURYEVA TS, MEDNIKOVA EI, DADASHEVA OA, POVALKO NB: The musculoskeletal apparatus of Japanese quail during hypodynamy. Folia Vet 42 (Suppl): 37-39, 1998.

JURÁNI M, VÝBOH P, LAMOŠOVÁ D, BAROŠKOVÁ Ž, SOMOGYIOVÁ E, BOĎA K, GAŽO K: The effect of a 90-day hypodynamy on the neurohumoral system, egg laying and metabolism of proteins in Japanese quail. In: Space Biology - Gravitational Physiology (in Slovak). K BOĎA (ed), SAV, Ústav fyziológie hospodárskych zvierat, Košice, 1984, pp 81-90.

KAMIYA H, SASAKI S, IKEUCHI T, UMEMOTO Y, TATSURA H, HAYASHI Y, KANEKO S, KOHRI K: Effect of simulated microgravity on testosterone and sperm motility in mice. $J$ Andrology 24: 885- 890, 2003.

MOREY-HOLTON ER, WRONSKI TJ: Animal models for simulated weightlessness. Physiologist 24: S45-S48, 1981.

RAY CA, VASQUES M, MILLER TA, WILKERSON MK, DELP MD: Effect of short-term microgravity and longterm hindlimb unloading on rat cardiac mass and function. J Appl Physiol 91: 1207-1213, 2001.

SABO V, BOĎA K, SHEPELEV EY, PETER V, NOSKIN D: Razvitije embryonov japonskoj perepelki v uslovijach nevesomosti. In: Space Biology - Gravitational Physiology (in Slovak). K BOĎA (ed), SAV, Ústav fyziológie hospodárskych zvierat, Košice, 1984, pp 255-262.

SABO V, CHRAPPA V, BOĎA K: Effect of long-term (84-days) hypodynamy on the efficiency of Japanese quails. Folia Vet 42 (Suppl): S59-S61, 1998.

SABO V, BOĎA K, GURYEVA TS, DADASHEVA OA, BELLA I: The study of postembryonic development of Japanese quail chicks under microgravity and load on the orbital station Mir. Folia Vet $\mathbf{4 5}$ (Suppl): S9-S11, 2001.

SAPP WJ, PHILPOTT DE, WILLIAMS CS, KATO K, STEVENSON J, VASQUEZ M, SEROVA LV: Effects of spaceflight on the spermatogonial population of rat semeniferous epithelium. FASEB $J$ 4: 101-104, 1990.

SHARMA CS, SARKAR S, PERIYAKARUPPAN A, RAVICHANDRAN P, SADANANDAN B, RAMESH V, THOMAS R, HALL JC, WILSON BL, RAMESH GT: Simulated microgravity activates apoptosis and NF- $\mathrm{KB}$ in mice testis. Mol Cell Biochem 313: 71-78, 2008. 
STROLLO F, RIONDINO G, HARRIS B, STROLLO G, CASAROSA E, MANGROSSA N, FERRETI C, LUISI M: The effect of microgravity on testicular androgen secretion. Aviat Space Environ Med 69: 133-136, 1998.

ŠKROBÁNEK P, HRBATÁ M, BARANOVSKÁ M, JURÁNI M: Growth of Japanese quail chicks in simulated weightlessness. Acta Vet Brno 73: 157-164, 2004.

ŠKROBÁNEK P, BARANOVSKÁ M, ŠÁRNIKOVÁ B, JURÁNI M: Effect of simulated microgravity on sexual development of female Japanese quail. Acta Vet Brno 77: 3-10, 2008.

ŠKROBÁNEK P, BARANOVSKÁ M, ŠÁRNIKOVÁ B, JURÁNI M, ZEMAN M, CIGÁNKOVÁ V: Effect of simulated microgravity on sexual development of male Japanese quail. Acta Vet Brno 78: 563-569, 2009.

ŠKROBÁNEK P, SABO V, BOĎA K, BARANOVSKÁ M, MRAVCOVÁ I: The capacity of Japanese quail hatchlings to adapt to hypodynamy. Folia Vet 45 (Suppl 1): S69-S70, 2001.

TASH JS, JOHNSON DC, ENDERS GC: Long-term (6-wk) hindlimb suspension inhibits spermatogenesis in adult male rats. J Appl Physiol 92: 1191-1198, 2002.

TISCHLER ME, HENRIKSEN EJ, MUNOZ KA, STUMP CS, WOODMAN CR, KIRBY CR: Spaceflight on STS-48 and earth-based unweighting produce similar effects on skeletal muscle of young rats. J Appl Physiol 74: 2161$2165,1993$.

WALTON K: Postnatal development under conditions of simulated weightlessness and space flight. Brain Res Rev 28: 25-34, 1998.

ZEMAN M, KOŠUTZKY J, BOBÁKOVÁ E: Testosterone concentration in the seminal plasma of cocks. Br Poult Sci 27: 261-266, 1986. 